\title{
ГІГІЄНІЧНІ ЗАХОДИ З ОПТИМІЗАЦІї УМОВ ФУНКЦІОНУВАННЯ ЗАКЛАДІВ ОХОРОНИ ЗДОРОВ'Я ТА ПРОФІЛАКТИКИ ЗАХВОРЮВАНЬ МЕДИЧНИХ ПРАЦІВНИКІВ
}

\author{
${ }^{1}$ Вінницький національний медичний університет імені М. І. Пирогова, м. Вінниця, Україна \\ ${ }^{2}$ КНП «Вінницький обласний центр післядипломної освіти медичних працівників», м. Вінниця, Україна
}

\begin{abstract}
Мета: провести гігієнічне обґрунтування заходів з оптимізації умов фрункціонування закладів охорони здоров'я та профілактики, ранньої діагностики порушень психічного здоров'я як основи професійних захворювань медичних працівників (МП) закладів охорони здоров'я.

Матеріали і методи. Використано метод теоретичного порівняльного аналізу даних України та міжнародного досвіду щодо стану профресійних захворювань і порушень психічного здоров'я як основи професійних захворювань МП закладів охорони здоров'я.

Результати. Проведено гігієнічне обґрунтування заходів з оптимізації умов функціонування закладів охорони здоров'я та профілактики, ранньої діагностики порушень психічного здоров'я як основи професійних захворювань МП закладів охорони здоров'я.

Профресійні шкідливі чинники є ризиком виникнення хвороб, загострення соматичних захворювань, фрормування хронічної патології, захворюваності з тимчасовою втратою працездатності медичних працівників. В Україні до основних травмонебезпечних галузей економіки та видів робіт належить охорона здоров'я - 74 \% (2582 травмовані особи, в т. ч. 82 - летальних випадки за період пандемії COVID-19). Це спричиняє підвищення медичних, соціальних, економічних втрат суспільства і держави.

Запропоновані види мотивації, які можна застосувати у державних або комунальних закладах охорони здоров'я (303) України як матеріальну, так і нематеріальну зацікавленість МП для створення ефективного мотиваційного механізму.

Висновки. Запропонована модель центрів охорони професійного здоров'я 3О3. Функціями цих закладів є: електронний моніторинг здоров'я та захворювання МП, диспансеризація, профрілактично-консультативна допомога, допомога щодо підготовки/перепідготовки/підвищення кваліфрікації медичних кадрів. Надані основні принципи профрілактичних заходів щодо професійних захворювань МП. На основі отриманих даних запропоновані заходи для покращення здоров'я МП: розробка відповідних нормативно-правових документів з охорони праці у медичній галузі, поліпшення умов праці, внутрішньолікарняного середовища, побутових умов для відпочинку, організації раціонального харчування, психологічного розвантаження шляхом створення центрів охорони професійного здоров'я.
\end{abstract}

КЛЮЧОВІ СЛОВА: медичний працівник; внутрішньолікарняне середовище; оптимізація умов праці; профрілактика професійних захворювань.

Для економічного, соціального розвитку держави здоров'язберігальна складова у найпоширенішій сорері трудової діяльності як медична галузь, в якій нараховують близько 170 медичних спеціальностей, є пріоритетною для стабільного та успішного розвитку держави, особливо в період реформи. Робота в медичній галузі найбільш складна та відповідальна за життя пацієнта і вимагає значних інтелектуальних, фрізичних, психоемоційних навантажень частіше в екстремальних умовах, при цьому фрахівці галузі охорони здоров'я повинні зберегти високу працездатність, стресостійкість [2]. Під час надання медичної допомоги пацієнтам на медичних працівників (МП) впливає багато професійно-шкідливих чинників: фрізичні (ультразвукове, електромагнітне, лазерне, радіаційне випромінювання, шум, вібрація, підвищений атмосорерний тиск, невідповідне природне та штучне освітлення робочого місця, невідповідні показники мікроклімату (температура, вологість, швидкість руху повітря)); хімічні (антибіотики, анестетики, хіміотерапевтичні та інші препарати, засоби особистої гігієни, дезінфікуючі та антисептичні засоби при обробці рук та приміщень); біологічні (повітрянокрапельні, гемоконтактні інфекції), важкість праці (робота у вимушеному положенні, стереотипні робочі рухи, надлишкове напруження аналізаторних систем) [8]. Також можна віднести і виникнення травматизму від нападів пацієнтів із психічними розладами, осіб наркологічних закладів, як це спостерігають в європейських країнах близько $50 \%$ усіх агресивних нападів, зафріксованих у психіатричних закладах на міжнародному рівні, та 62 \% медичних сестер у різних країнах світу зазнають фрізичного насильства протягом року, які призводять до 37 \% фрізичних травм персоналу. Можливо і комплексна дія цих чинників одночасно $[17,18]$.

Найшкідливішими чинниками у роботі МП багато науковців відзначають розумову і нервовоемоційну напруженість, яка $€$ ризиком за- 
хворювання на емоційні розлади, емоційне виснаження, професійне вигорання $[4,5,13$, $14,16]$, яке в новій класифрікації хвороб МКХ-11 ВОО3 (Женева 2019 р.) у розділі «Фактори, що впливають на стан здоров'я або контакт зі службами системи охорони здоров'я» визнано як професійний синдром вигорання, що виникає внаслідок «хронічного стресу на робочому місці, 3 яким працівник своєчасно не впорався», і віднесений до категорій «Розлади адаптації» - F43; «Вигорання» - Z73.0; «Неврастенія» - F48 [3]. Хронічний стрес на робочому місці характерний для всіх медичних спеціальностей у всьому світі, так в Україні складає 80 \% лікарів-психіатрів, психотерапевтів, наркологів, а серед медичних сестер психіатричного профрілю - 62,9 \%, лікарівстоматологів - $61 \%$, акушерів-гінекологів - $30 \%$, лікарів-педіатрів - 21 \% [2], а у США серед лікарів відзначають в 45-54\%, у лікарів Швейцарії - 43,3 \% і серед медичних сестер та акушерок спостерігали у 28,7 \% хронічний стрес на робочому місці, при цьому МП мають намір залишити профресію [5, 15].

Профресійні шкідливі чинники є ризиком виникнення хвороб, загострення соматичних захворювань, фрормування хронічної патології, захворюваності 3 тимчасовою втратою працездатності МП [6].

Мета роботи: провести гігієнічне обґрунтування заходів з оптимізації умов функціонування закладів охорони здоров'я та профрілактики, ранньої діагностики порушень психічного здоров'я як основи професійних захворювань МП закладів охорони здоров'я.

Матеріали і методи. Використано метод теоретичного порівняльного аналізу даних України та міжнародного досвіду щодо стану професійних захворювань і порушень психічного здоров'я як основи професійних захворювань МП закладів охорони здоров'я.

Результати дослідження та їх обговорення. За офріційними статистичними даними, в Україні близько 1,1 млн МП усіх спеціальностей працюють в небезпечних, шкідливих умовах праці. В Україні достовірних статистичних даних щодо профресійних захворювань в галузі медицини немає. Професійні захворювання залежать від багатьох чинників: більшість МП непокоїться втратити роботу і, тому, приховує наявність патології, пов'язаної з профресійною діяльністю. У разі погіршення їх здоров'я (35,6 \% жінок і 35,5 \% чоловіків лікарів-психіатрів) займаються самолікуванням. Аналогічна тенденція і серед середнього медичного персоналу (СМП) (жінки - 31,3 \%, чоловіки - 31,5 \%). Не звертають увагу на хворобу 25,8 \% лікарів-психіатрів жіночої статті та 23,1 \% чоловіків СМП психіатричного профрілю, що призводить до виникнення професійних захворювань та фрормування хронічної патології $[9,10]$.

Аналіз професійної захворюваності в Україні за 15 років (з 2001 до 2015 р.) показує 1092 випадки (1,2 \%) серед МП відносно 91562 випадки взагалі в різних галузях. Найбільший рівень профресійних захворювань в медичній галузі відзначено у 2004 р. 0,76 на 10 тис. працюючих (103 випадки) і у 2006 р. 0,74 на 10 тис. працюючих (100 випадків) [6]. 3 подіями пандемії у 2020-2021 рр. на COVID-19 в Україні за 1 квартал 2021 р. до Фонду соціального страхування надійшло та зареєстровано 10970 повідомлень про нещасні випадки/гострі професійні захворювання (отруєння) порівняно 31 кварталом 2020 р., кількість звернень збільшилась у 8,3 раза (з 1317 до 10 970), $з$ летальними наслідками зросла у 1,5 раза (3 285 до 426). Від їх загальної кількості МП склали 87,8 \% (9634), найчастіше це працівники віком від 50 до 59 років. Ці події показали, що потрібне покращення умов праці МП, відповідне фінансування галузі охорони здоров'я повинно бути не тільки під час пандемій, а й має бути пріоритетним напрямком держави, що $€$ запорукою збереження кадрового потенціалу, здоров'я та життя населення країни, як це $\epsilon$ в європейських країнах, в яких акцент у галузі охорони здоров'я покладено на комфорт та культуру праці МП будь-якого рангу [11].

В Україні до основних травмонебезпечних галузей економіки та видів робіт належить охорона здоров'я - 74 \% (2582 травмовані особи, в т. ч. 82 - летальних випадки за період пандемії COVID-19). Це спричиняє підвищення медичних, соціальних, економічних втрат суспільства і держави. Кількість страхових нещасних випадків у медичній галузі, порівняно 31 кварталом 2020 р., збільшилась у 42,5 раза (з 61 до 2592 МП), а 3 летальними наслідками зросла у 82 рази (3 1 до 82 МП) за період пандемії COVID-19.

За останні роки в Україні на законодавчому рівні прийнято такі нормативно-правові документи (табл. 1).

Незрозуміла ситуація виникла щодо подачі Звіту про травматизм на виробництві у 20___ р. (форма № 7), затвердженого наказом Державною службою статистики від 18.08.14 р. за № 242, який відмінений наказом від 21.10.19 р. за № 348, але фрорма аналогічного звіту станом на сьогодні ще не затверджена.

На сьогодні в Україні не створені як економічні, так і правові механізми захисту МП від небезпечних умов праці, в яких вони змушені працювати і ризикувати своїм здоров'ям, життям заради досягнення життєвого добробуту. Не прийнятий Закон України від 22.05.2008 р. № 2538 «ро соціальний захист медичних та фармацевтичних працівників, працівників охорони здоров'я». Відповідно до Указу Президента України «Про Концепцію розвитку охорони здоров'я населення України» від 2000 р. № 1313/2000, який передбачав вдосконалення системи охорони здоров'я щодо забезпечення медичними кадрами, зменшення негативного впливу професійних шкідливих фракторів на здоров'я та відновлення працездатності МП. Для досягнення цілей необхідно проводити заходи щодо збереження та зміцнення здоров'я як населення, так і медичних працівників, які за це відповідають, і, тим самим, спонукати до продов- 
Таблиця 1. Основні законодавчі та нормативно-правові документи, в яких регламентуються питання щодо охорони праці, медико-соціальної експертизи, випадків смерті та ін.

\begin{tabular}{|c|c|}
\hline $\begin{array}{c}\text { Номер документа/рік } \\
\text { затвердження }\end{array}$ & Назва документа \\
\hline № 322-VIII від 1971 р. & Кодекс законів про працю України (КЗпП) \\
\hline № 2694-XII від 1992 р. & Закон України «Про охорону праці» \\
\hline $\begin{array}{l}\text { № 2801-XII від } 1993 \text { р. (редакція } \\
\text { від 23.04.21 р., підстава - 1357-XI) }\end{array}$ & Закон України «Основи законодавства України про охорону здоров'я» \\
\hline № 78 від 1998 р. & $\begin{array}{l}\text { Наказ МОЗ України «Про заходи по організації системи надання медичної } \\
\text { допомоги працівникам охорони здоров'я» }\end{array}$ \\
\hline № 1313/2000 від 2000 р. & $\begin{array}{l}\text { Указ Президента України «Про Концепцію розвитку охорони здоров'я } \\
\text { населення України» }\end{array}$ \\
\hline № 1112 від 2004 р. & $\begin{array}{l}\text { Постанова КМУ «Деякі питання розслідування та ведення обліку } \\
\text { нещасних випадків, професійних захворювань і аварій на виробництві» }\end{array}$ \\
\hline $\begin{array}{l}\text { Проект Закону України № } 2538 \\
\text { від 22.05.2008 р. }\end{array}$ & $\begin{array}{l}\text { Закон України «Про соціальний захист медичних та фрармацевтичних } \\
\text { працівників, працівників охорони здоров'я» }\end{array}$ \\
\hline № 1317 від 2009 р. & Постанова КМУ «Питання медико-соціальної експертизи» \\
\hline № 561 від 2011 р. & $\begin{array}{l}\text { Наказ МОЗ України «Про затвердження Інструкції про встановлення груп } \\
\text { інвалідності» }\end{array}$ \\
\hline № 420 від 2012 р. & $\begin{array}{l}\text { Наказ МОЗ України «Про затвердження Порядку та Критеріїв } \\
\text { встановлення медико-соціальними експертними комісіями ступеня } \\
\text { стійкої втрати профресійної працездатності у відсотках працівникам, } \\
\text { яким заподіяно ушкодження здоров'я, пов'язане з виконанням трудових } \\
\text { обов'язків» }\end{array}$ \\
\hline № 248 від 2014 р. & $\begin{array}{l}\text { Наказ МОЗ України «Про затвердження Державних санітарних норм } \\
\text { та правил «Гігієнічна класифрікація праці за показниками шкідливості } \\
\text { та небезпечності фракторів виробничого середовища, важкості та } \\
\text { напруженості трудового процесу» }\end{array}$ \\
\hline № 394 від 2020 р. & $\begin{array}{l}\text { Постанова КМУ, Перелік професійних захворювань, затверджений } \\
\text { Постановою КМУ від } 8 \text { листопада } 2000 \text { р. № 1662, доповнено пунктом } 4 \\
\text { розділу V «Захворювання, викликані дією біологічних фракторів» }\end{array}$ \\
\hline № 1 від 2021 р. & $\begin{array}{l}\text { Постанова КМУ «Деякі питання розслідування випадків смерті окремих } \\
\text { категорій медичних працівників» }\end{array}$ \\
\hline & https://zakon.rada.gov.ua/rada/show/\#Text \\
\hline
\end{tabular}

ження активного довголіття і тривалості життя. Індекс людського розвитку (IЛР) щорічно публікують у Програмі розвитку Організації Об'єднаних Націй, що оприлюднює дані про стан здоров'я населення країн світу, який залежить від соціально-економічного розвитку, від рівня профресійної освіти (грамотності та освітленості), рівня життя і нерівності (дитяча смертність, якість харчування), гендерних особливостей (індекс народжуваності, материнської смертності, народжуваності у підлітковому віці), екологічної ситуації в країні та ін. У Норвегії ІЛР дорівнює 0,954, тривалість життя становить понад 82,3 року (2018р.), при цьому в Китаї тривалість життя перевищує всі країни світу і становить 84,7 року, в Україні ІЛР дорівнює 0,750 і тривалість життя становить 70,1 року. Порівняно $з$ 1990-2018 рр., ІЛР в Україні збільшився на 6,3 \% з 0,705 до 0,750, зросли тривалість життя при народженні на 2,1 року та середня кількість років навчання на 2,2 року, кількість років навчання збільшилася на 2,7 року, але рівень життя погіршився із-за скорочення валового національного доходу на душу населення на 25,6 \% за останні 28 років (1990-2018рр.) [19]. Концепцією передбачалось забезпечити гарантоване створення правових, економічних, управлінських механізмів реалізації конституційних прав громадян України на охорону здоров'я, медичну допомогу та медичне страхування (яке на даний час відсутнє), а також керований ринок платних медичних послуг (послуги під час пандемії COVID-19 взагалі були некеровані й за більшість послуг платили пацієнти «з власних кишень») [11].

Мета реалізації Концепції:

1. Доступність МП 303, незалежно від профрілю та потужності закладу, до кваліфікованої медико-соціальної, психологічної допомоги/підтримки.

2. Електронний облік ранньої діагностики профресійних захворювань МП із використанням новітніх/сучасних інформаційних технологій та удосконалення корекції/лікування.

3. Постійне проведення заходів щодо покращення стану здоров'я МП, зменшення первинної, вторинної захворюваності, загострення хронічної, професійної захворюваності, 3 тимчасовою втратою працездатності, інвалідності.

4. Проведення заходів щодо покращення працездатності, матеріальної і нематеріальної мотивації МП (рис. 1).

Види мотивації, які ми пропонуємо застосувати у державних або комунальних 303 України як матеріальну, так і нематеріальну зацікавленість медичних працівників для створення ефективного мотиваційного механізму, подано на рисунку 1. 


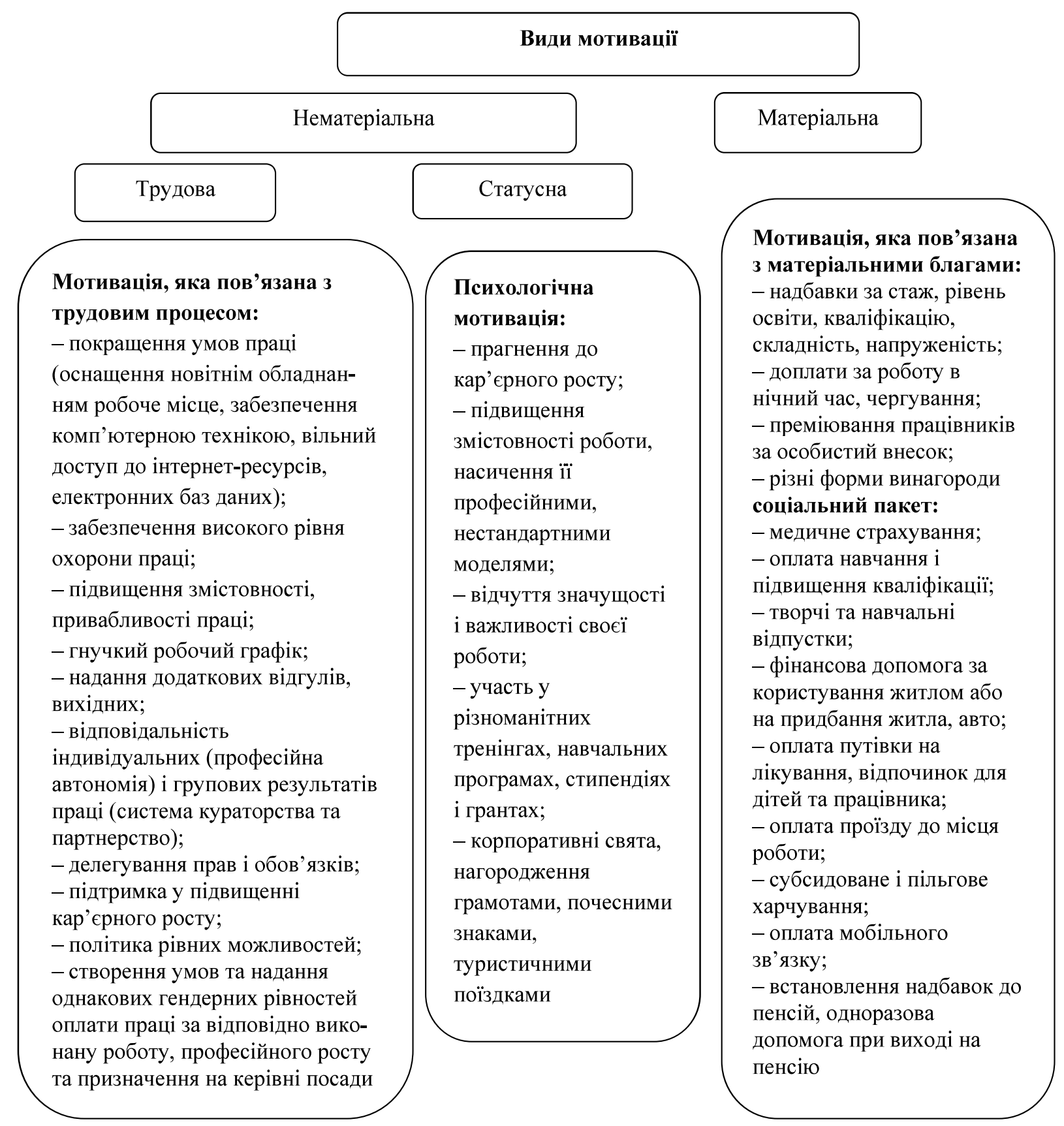

Puc. 1. Схема мотиваційної складової професійної діяльності медпрацівників (склали автори).

Існуюча система соціального захисту в Україні МП від професійних чинників має певні недоліки:

1. Основну частину економічного тягаря у випадку профресійного ризику несе суспільство, а не роботодавець, медичний заклад, держава.

2. Відсутність обґрунтованих правових, гігієнічних, медико-біологічних, психофрізіологічних норм/методів в оцінці професійних ризиків у будь-якій галузі охорони здоров'я.

3. Система «пільг та компенсацій» у шкідливих умовах праці 303 зведена нанівець [12].

У країнах ЄС соціальний пакет має такі складові, які враховують головне у роботі медичних працівників: забезпечення здоров'я шляхом удосконалення багатьох факторів і умов праці, мотивація праці, навчання, підвищення кваліфікації, соціальна підтримка в різних фрормах - відпочинок, санаторно-курортне лікування, подорожі, спортивні змагання тощо. До 50 \% соціального пакету в країнах ЄС припадає на різні види страхування, але головним $є$ медичне страхування і особливо це необхідно медичним працівникам у різних галузях із різними професійними ризиками. Соціальний пакет у нашій державі поширений лише у великих вітчизняних компаніях, які бажають вийти на міжнародний ринок країн світу, тому дотримуються цивілізованих принципів соціальної відповідальності за своїх працівників. Трудовим законодавством України не передбачений соціальний пакет, але є обов'язкові страхові нарахування на заробітну плату в соціальний фонд [1, 7]. 
Будівництво багатьох лікувально-профрілактичних закладів відбувалося за принципом «коридорної системи» відповідно до ДБН В.2.2.10-2001 «Будинки і споруди. Заклади охорони здоров'я» і на сьогодні на заміну чинному нормативному документу ДБН В.2.2-10-2001 «Будинки і споруди. Заклади охорони здоров'я» (зі зміною № 2, наказ Міністерства регіонального розвитку, будівництва та житлово-комунального господарства України від 20.09.2013 р. № 454) готується новий ДБН В.2.2-10:2019 «Будинки і споруди. Заклади охорони здоров'я». А поки умови для МП створені за старими нормативами і вони виконують свій професійний обов'язок в будь-якій системі забудови лікарень (децентралізована, централізована, змішана), яка не враховує комфортність як для самих хворих, так і для медичних працівників. Усі гігієнічні вимоги до планування земельної ділянки, до території лікарні, до мікроклімату, природного та штучного освітлення, санітарно-гігієнічного режиму прописані, але, при цьому, за 15 років (2001-2015 рр.) у структурі профресійних захворювань серед медичних працівників в Україні, на жаль, зросла захворюваність на туберкульоз (87,7 \% на робочому місці) і на період 2020-2021 pp. - на COVID-19 [6].

щодо ВІЛ-інфрікування медичного персоналу в Україні за період 2001-2015 рр. зареєстровано 2 випадка на робочому місці, при цьому сероепідмоніторінг ВІЛ-інфекції серед МП не проводять, тому статистичні дані відсутні. Система охорони здоров'я зупинилась на багато років i, на жаль, перебуває на шляху реформування, а МП, пацієнти вимушені працювати і лікуватися в умовах, які не відповідають європейським стандартам.

За останні роки недостатньо науково обґрунтованих даних щодо гігієнічних основ оптимізації умов праці для медичного персоналу шляхом зміни архітектурно-планувальних рішень до будівель 303, що впливає на санітарно-гігієнічні умови внутрішньолікарняного середовища, на ефективність праці, на психофізіологічний стан МП у порівнянні, як це проводять в країнах ЄС. Якщо лікарня не відповідає вимогам, яка була раніше побудована, на її місці будують сучасну лікарню в країнах ЄC [18].

За кордоном дуже популярні центри психічного здоров'я, такі центри спрямовані на всіх громадян держави для покращення/доступності надання безкоштовної медичної допомоги щодо профрілактики та зменшення психічних захворювань/розладів. Наприклад, у Польщі, Литві та багатьох європейських країнах побудовані центри психічного здоров'я, в яких проводять профрілактичну роботу щодо покращення психічного здоров'я населення, та, при необхідності, направляють на лікування при загостренні хвороби. Ми пропонуємо створення таких центрів охорони професійного здоров'я у 303 для МП, оскільки і МП потребують таку допомогу. Діяльність таких центрів повинна передбачати:
- електронний моніторинг здоров'я МП, професійного захворювання, диспансеризації з використанням сучасних інформаційних технологій (статистичний відділ);

- кабінет для профрілактичних, диспансерних медичних оглядів з сучасним технологічним обладнанням 3 обов'язковим параклінічним i фрункціональним дослідженнями;

- юридичний відділ, який замінить профспілкові організації, які не виконують свої функції на сьогодні;

- профрілактично-консультативний відділ (мультидисциплінарна група - психолог та інші фахівці, які стимулюють виховання у МП ставлення до свого здоров'я як суспільної цінності та засад здорового способу життя);

- відділ 3 підготовки/перепідготовки/підвищення кваліфрікації медичних кадрів як окрема структура, не підпорядкована відділу кадрів. Функції цього відділу: надавати консультативну допомогу - де, коли, як краще пройти курси підвищення кваліфікації; санітарно-освітню допомогу із питання профрілактики загальної та професійної захворюваності, профресійних ризиків, залежно від спеціальностей, характеру професійних ризиків, вікового та статевого чинників. Цей відділ також може надавати консультації інтернам.

Основними принципами профрілактичних заходів щодо професійних захворювань медичних працівників є:

1. Дотримання санітарно-гігієнічних і профрілактичних правил та норм (заходи із профілактики внутрішньолікарняних інфекцій, інструктивно-методичні документи на робочих місцях, безкоштовне забезпечення колективними та індивідуальними засобами захисту).

2. Забезпечення кожного МП соціальним пакетом та обов'язковим страхуванням на випадок захворювання на інфекційні хвороби, отримання тимчасової втрати працездатності, інвалідності. Облаштування на кожному територіальному рівні Центру охорони професійного здоров'я.

3. Постійне проведення атестації робочих місць за певними критеріями умов праці.

4. Проведення тренінгів, лекцій, бесід щодо профрілактичних, соціальних заходів.

\section{Висновки}

На основі отриманих даних пропонуємо такі заходи:

1. Розробка відповідних нормативно-правових документів з охорони праці у медичній галузі, які повинні бути враховані у колективному договорі.

2. Профрілактичні заходи проводити шляхом покращення умов праці, побутових умов для відпочинку, психологічного розвантажування, організації раціонального харчування.

3. Створення центрів у 303 для МП - центрів охорони професійного здоров'я для зміцнення здоров'я медичного працівника шляхом фрормування більш відповідального ставлення до власного здоров'я та мотивації на здоровий спосіб життя як самого себе, так і пацієнтів. 
Перспективи подальших досліджень. 3 огляду наукових праць на негативні тенденції стану здоров'я медичних працівників щодо профресійних захворювань пріоритетного вивчення потребують чинники ризику професійних захворювань, умови праці, побутові умови для відпочинку, причини пізньої діагностики, заходи профрілактики і проведення постійного аналізу стану профресійної захворюваності у МП.

\section{Список літератури}

1. Баранник Л. Б. Соціальний пакет як атрибут сучасного підприємства / Л. Б. Баранник // Вісник Київського національного університету імені Т. Шевченко. - 2011. - № 124-125. - С. 62-65.

2. Баркевич В. А. Гігієна праці і стан здоров'я медичних працівників різних спеціальностей / В. А. Баркевич // Військова медицина України. - 2017. - Т. 17, № 1. - С. 54-58.

3. ВООЗ [Електронний ресурс]. - Режим доступу : https://www.umj.com.ua/article/158015/shhonaspravdi-zatverdili-vmkh-11.

4. Кавецька Н. А. Професійне вигорання серед медичних працівників: психологічні аспекти / Н. А. Кавецька, С. М. Андрейчин, Н. 3. Ярема // Медична освіта. - 2020. - № 4. - C. 27-31. DOI: 10.11603/ME.2414-5998.2020.4.11654. 5. Марута Н. О. Особливості емоційного вигорання в працівників сорери охорони неврологічного й психічного здоров'я / Н. О. Марута, О. С. Чабан, Г. Ю. Каленська // Міжнародний неврологічний журнал. - 2019. - № 7 (109). C. 22-29. DOI: 10.22141/2224-0713.7.109.2019.183009.

6. Профресійна захворюваність медичних працівників в Україні як медико-соціальна проблема / А. М. Нагорна, М. П. Соколова, І. Г. Кононова // Український журнал з проблеми медицини праці. - 2016. - № 2 (47). - С. 3-16.

7. Новак І. М. Соціальний пакет: особливості формування та управління / І. М. Новак // Ринок праці та соціальнотрудові відносини. - 2008. - № 1. - С. 115-120.

8. Салманов А. Охорона праці медичних працівників у системі інфекційного контролю / А. Салманов // Журнал заступника головного лікаря. - 2017. - № 3. - С. 34-44.

9. Ставлення медичних працівників сфери охорони психічного здоров'я до власного здоров'я / В. В. Чорна, В. М. Махнюк, С. С. Хлєстова, Г.В.Чайка // Медичні перспективи. - 2021. - Т. XXVI, № 2. - С. $188-196$.

10. Фактори ризику професійних захворювань медичних працівників (огляд літератури) / Л. П. Бондар, А. О. Боб, Р. Я. Бондар, Т. В. Бондар // Вісник наукових досліджень. - 2018. - № 2. - С. 6-10.

11. Чорна В. В. Порівняльний аналіз фрінансування сфери охорони здоров'я України та країн Європейського союзу / В. В. Чорна // Вісник соціальної гігієни та організації охорони здоров'я України. - 2021. - № 1 (87). - С. $45-49$.

12. Чорна В. В. Мотивація і працездатність медичних працівників ссрери охорони психічного здоров'я як предиктор їхнього психологічного благополуччя / В. В. Чорна // Довкілля та здоров'я. - 2020. - № 4 (97). - C. 53-62.

13. A cross-sectional study of job burnout, psychological attachment, and the career calling of Chinese doctors / S. Zhan, J. Wang, F. Xie, D. Yin [et al.] // BMC Health Serv Res. - 2020. - Vol. 20 (1). - P. 193. DOI: 10.1186/s12913-020-4996-y. 14. Burnout in mental health professionals and the measures to prevent it / V. V. Chorna, V. M. Makhniuk, N. G. Pshuk [et al.] // Georgian medical al news. - 2021. - No. 1 (310). - P. 113-118.

15. Hämmig $O$. Explaining burnout and the intention to leave the profession among health professionals - a cross-sectional study in a hospital setting in Switzerland / O. Hämmig // BMC Health Services Research. - 2018. - 18 (1). - P. 785. DOI:10.1186/s12913-018-3556-1.

16. Prevalence and Predictors of Burnout in Midwives: F Systematic Review and Meta-Fnaiysis / N. Suleiman-Martos, L. Albendin-Garcia, J. L. Gomez-Urguiza // Int. J. Environ. Res. Public Health. - 2020. - Vol. 17 (2).pii:E641. doi:10.3390/ ijerph17020641

17. Prevflence of injuries among the population of the Vinnisa city / V. V. Chorna, V. V. Makhniuk, S. S. Khliestova \& T. Shevchuk // Georgian medical al news. - 2020. - No. 1. - P. 17-21.

18. Ulrich R. S. Psychiatric ward design can reduce aggressive behavior / R. S. Ulrich, L. Bogren, S. Gardiner // Journal of Environmental Psychology. - 2018. - Vol. 57. - P. 53-66. https://DOI.org/10.1016/j.jenvp.2018.05.002.

19. UNDP Human Development Report 2019: Overview. Beyond income, beyond averages, beyond today: Inequalities in human development in the 21st century. New York, NY 10017 USA: United Nations Development Programme One United Nations Plaza. Available from http://hdr.undp.org/sites/default/files/hdr2019.pdf.

\section{References}

1. Barannik, L. (2011). Sotsialnyy paket yak atrybut suchasnoho pidpryyemstva [Social package as an attribute of a modern enterprise]. Visnyk Kyivskoho natsionalnoho universytetu imeni T. Shevchenko - Bulletin of Taras Shevchenko Kyiv National University, 124-125, 62-65 [in Ukrainian].

2. Barkevuch, V.A. (2017). Hihiyena pratsi i stan zdorovya medychnykh pratsivnykiv riznykh spetsialnostey [Occupational health and health of medical professionals of various specialties]. Viyskova medytsyna Ukrayiny - Military Medicine of Ukraine, 17 (1), 54-58 [in Ukrainian].

3. (2019). VOOZ. [WHO]. Geneva. - www.umj.com.ua. -https://www.umj.com.ua/article/158015/shhonaspravdi-zatverdiliv-mkh-11

4. Kavetskaya, N.A, Andreychin, S.M, \& Yarema, N.Z (2020). Profesiyne vyhorannya sered medychnykh pratsivnykiv: psykholohichni aspekty [Occupational burnout among health professionals: psychological aspects]. Medychna osvita Medical Education, 4, 27-31. Doi 10/11603 / me.2414-5998.2020.4 / 11654 [in Ukrainian]. 
5. Maruta, N.O, Chaban, O.S, \& Kalenskaya, G.Yu. (2019). Osoblyvosti emotsiynoho vyhorannya v pratsivnykiv sfery okhorony nevrolohichnoho y psykhichnoho zdorovya [Features of emotional burnout in neurological and mental health workers]. Mizhnarodnyy nevrolohichnyy zhurnal -International Journal of Neurology, 7 (109), 22-29. Doi: 10.22141 / $2224-$ 0713.7.109.2019.183009 [in Ukrainian].

6. Nagornaya, A.M, Sokolova, M.P, \& Kononova, I.G (2016). Profesiyna zakhvoryuvanist medychnykh pratsivnykiv v Ukrayini yak medyko-sotsialna problema [Occupational morbidity of medical workers in Ukraine as a medical and social problem]. Ukrayinskyy zhurnal z problemy medytsyny pratsi - Ukrainian Journal of Occupational Medicine, 2 (47), 3-16 [in Ukrainian].

7. Novak, I.M (2008). Sotsialnyy paket: osoblyvosti formuvannya ta upravlinnya [Social package: features of formation and management]. Rynok pratsi ta sotsialno-trudovi vidnosyny - Labor Market and Social and Labor Relations, 1, 115-120 [in Ukrainian].

8. Salmanov, A. (2017). Okhorona pratsi medychnykh pratsivnykiv u systemi infektsiynoho kontrolyu [Occupational safety of medical workers in the system of infection control]. Zhurnal zastupnyka holovnoho likarya - Journal of the Deputy Chief Physician, 3, 34-44 [in Ukrainian].

9. Chorna, V.V, Makhnyuk, V.M, Khlestova, S.S \& Chaika, G.V (2021). Stavlennya medychnykh pratsivnykiv sfery okhorony psykhichnoho zdorovya do vlasnoho zdorovya [Attitudes of mental health professionals towards their own health]. Medychni perspektyvy - Medical Perspectives, XXVI (2), 188-196 [in Ukrainian].

10. Bondar, L.P, Bob, A.O, Bondar, R.Ya. \& Bondar, T.V (2018). Faktory ryzyku profesiynykh zakhvoryuvan' medychnykh pratsivnykiv (ohlyad literatury) [Risk factors for occupational diseases of medical workers (literature review)]. Visnyk naukovykh doslidzhen - Bulletin of Scientific Research, 2, 6-10 [in Ukrainian].

11. Chorna, V.V. (2021). Porivnyalnyy analiz finansuvannya sfery okhorony zdorovya Ukrayiny ta krayin Yevropeyskoho soyuzu [Comparative analysis of health care financing in Ukraine and the European Union]. Visnyk sotsialnoyi hihiyeny ta orhanizatsiyi okhorony zdorovya Ukrayiny - Bulletin of Social Hygiene and Health Care Organization of Ukraine, (1), 45-49.https://doi.org/10.11603/1681-2786.2021.1.12142 [in Ukrainian].

12. Chorna, V.V. (2020). Motyvatsiya i pratsezdatnist medychnykh pratsivnykiv sfery okhorony psykhichnoho zdorovya yak predyktor yikh psykholohichnoho blahopoluchchya [Motivation and efficiency of mental health care workers as a predictor of their psychological well-being]. Dovkillya ta zdorovya - Environment and Health, 4 (97). 53-62. DOI: https://doi. org/10.32402/dovkil2020.04.053 [in Ukrainian].

13. Zhang, S., Wang, J., Xie, F., \& Yin, D. (2020). A cross-sectional study of job burnout, psychological attachment, and the career calling of Chinese doctors. BMC Health Serv. Res. 20(1), 193. doi: 10.1186/s12913-020-4996-y

14. Chorna, V.V., Makhniuk, V.M., \& Pshuk, N.G. (2021). Burnout in mental health professionals and the measures to prevent it. Georgian Medical al News, 1 (310), 113-118.

15. Hämmig, O. (2018). Explaining burnout and the intention to leave the profession among health professionals - a crosssectional study in a hospital setting in Switzerland. BMC Health Services Research, 18(1), 785. doi:10.1186/s12913-0183556-1.

16. Suleiman-Martos, N., Albendin-Garcia, L., \& Gomez-Urguiza, J.L. (2020). Prevalence and Predictors of Burnout in Midwives: F Systematic Review and Meta-Fnaiysis. Int J Environ Res Public Health, 17 (2). pii:E641. doi:10.3390/ ijerph17020641.

17. Chorna, V.V., Makhniuk, V.V, Khlestova, S.S. \& Shevchuk, T. (2020). Prevflence of injuries among the population of the Vinnytsia city. Georgian Medical al News, 1, 17-21

18. Ulrich, R.S., Bogren, L., Gardiner, S. (2018). Psychiatric ward design can reduce aggressive behavior. Journal of Environmental Psychology, 57, 53-66. https://doi.org/10.1016/j.jenvp.2018.05.002

19. UNDP (2019). Human Development Report 2019: Overview. Beyond income, beyond averages, beyond today: Inequalities in human development in the 21st century. New York, NY 10017 USA: United Nations Development Programme One United Nations Plaza. Retrieved from: http://hdr.undp.org/sites/default/files/hdr2019.pdf.

\section{HYGIENIC MEASURES TO OPTIMIZE THE FUNCTIONING OF HEALTH CARE FACILITIES AND DISEASE PREVENTION OF HEALTH WORKERS}

V. V. Chorna ${ }^{1}$, L. B. Furman'2, V. M. Podolian ${ }^{1}$

${ }^{1}$ M. Pyrohov National Medical University, Vinnytsia, Ukraine

${ }^{2}$ Vinnytsia Regional Center for Postgraduate Education of Medical Workers, Vinnytsia, Ukraine

Purpose: to carry out a hygienic substantiation of measures to optimize the functioning of health care facilities and prevention, early diagnosis of mental health disorders as the basis of occupational diseases of health care facilities.

Materials and Methods. The method of comparative theoretical analysis of data of Ukraine and international experience on the state of occupational diseases and mental health disorders as the basis of occupational diseases of health care institutions is using.

Results. The article provides a hygienic justification of measures to optimize the functioning of health care facilities and prevention, early diagnosis of mental health disorders as the basis of occupational diseases of health care facilities.

Occupational harmful factors are the risk of disease, exacerbation of somatic diseases, the formation of chronic pathology, morbidity with temporary disability of health workers (MP). In Ukraine, the main traumatic sectors of the economy and types of work include health care - $74 \%$ (2582 injured, including 82 -fatalities during the pandemic COVID-19) and causes increased medical, social, economic losses to society and states. 
The types of motivation that can be used in state or municipal CHCs of Ukraine, both tangible and intangible interest of MS to create an effective motivational mechanism.

Conclusions. The model of "Occupational Health Centers" of the CHP is proposing. The functions of these institutions include electronic monitoring of health and diseases of MP, medical examination, preventive counseling, assistance in training/retraining / advanced training of medical personnel. Based on the obtained data, measures are proposing to improve the health of MP: development of relevant legal documents on health and safety in the medical field, improvement of the in-hospital environment, nutrition, psychological relief by creating "Occupational Health Centers".

KEY WORDS: medical worker; in-hospital environment; optimization of working conditions; prevention of occupational diseases.

Рукопис надійшов до редакції 23.06.2021 р.

\section{Відомості про авторів:}

Чорна Валентина Володимирівна - кандидат медичних наук, доцент кафедри медицини катастрофр та військової медицини Вінницького національного медичного університету імені М. І. Пирогова;

тел.: +38(043) 266-12-93.

Фурман Лариса Борисівна - директор КНП «Вінницький обласний центр післядипломної освіти медичних працівників».

Подолян Володимир Миколайович - кандидат медичних наук, доцент касредри медицини катастрофр та військової медицини Вінницького національного медичного університету імені М. І. Пирогова;

тел.: +38(043) 266-12-93. 